\title{
Persepsi Pentingnya Inovasi Dalam Organisasi
}

\author{
Mochamad Edwar Romli \\ Dosen PNS DPK L2 Dikti
}

\begin{abstract}
ABSTRAK
Inovasi merupakan suatu penemuan baru, walaupun bukan merupakan suatu yang benar-benar baru. Inovasi penting dalam organisasi, sehubungan dengan ini rumusan masalah yang diinginkan adalah bagaimana persepsi pentingnya inovasi dalam organisai.
\end{abstract}

Kata Kunci : Inovasi dalam organisasi

\section{ABSTRACT}

Innovation is a new invention, although it is not really new. Important innovations in organizations, in connection with this desired problem formulation is how the perception of the importance of innovation in organizations.

Keywords: Innovation in organizations

\section{A. PENDAhULUAN}

Organisasi merupakan perserikatan untuk mencapai tujuan bersama H.B Siswanto (2006:85) menyatakan organisasi adalah sasaran atau hubungan antar bagian, komponen dan posisi dalam suatu perkumpulan. Dari pengertian diatas dapat disimpulkan tentang organisasi itu sebagai berikut :

a. Dalam organisasi ada kelompok atau orang

b. Ada hubungan diantara anggota organisai

c. Organisasi mempunyai tujuan yang ingin dicapai Nila sari dan Sri Wilujeng (2006:75) menyatakan organisasi adalah kumpulan orangorang yang terdiri dari dua orang atau lebih yang bekerja sama untuk mencapai tujuan.

Didalam suatu organisasi selalu ada tugas-tugas pekerjaan yang harus dilakukan. Perlaksanaan tugas-tugas itu membutuhkan peralatan kerja yang selalu sesuai dengan inovasi yang ada.

Penyediaan persoalan kerja itu memerlukan inovasi - inovasi agar pekerjaan dapat dilakukan dengan lebih mudah cepat atau efesien dan efektif (James AF. Stoner, 1986 : 57).

Carol Kinsey Goman menyatakan organisasi merupakan kemampuan untuk menciptakan/berkuasa atau mengkoordinir suatu gagasan baru, kreatifitas berkaitan dengan daya pikir kita yitu memikirkan ide-ide atau gagasan baru, bahwa dalam membentuk produk barang maupun jasa. Tetapi masih dalam bentuk pemikiran kita saja. Jika ide itu sudah diwujudkan maka produk yang dihasilkan merupakan produk inovasi atau produk baru itu tidak selalu benarbenar baru. 
$\begin{aligned} & \text { Eman } \\ & \text { menyatakan } \\ & \text { inovasi }\end{aligned} \begin{array}{r}\text { (2008:59) } \\ \text { adalah }\end{array}$
pendayagunaan sumber nilai baru
yang berbeda dari yang sebelumnya.
Menurut Eman Suherman (2008:59)
inovasi adalah pengalihan ide- ide baru
hasil kreativitas baru dalam bentuk
produk baru, seri baru maupun
metode-metode produk baru. Beberapa jenis inovasi dimasa pemerintahan presiden Jokowidodo saat ini beliau sangat mempengaruhi orang yang memiliki keterampilan, keahlian bukan hanya orang yang memiliki pengetahuan bisnis yang tinggi saja tetapi dalam kenyataannya tidak mampu bekerja, tidak mampu melakukan perubahan. Inovasi merupakan suatu yang mampu melakukan perubahan atau bahkan pembawaan melalui produk-produk yang diperlukan. Inovasi tidak hanya berupa produk barang seperti handphone, televisi, mobil, motor, sepeda, jam tangan, mode pakaian, dan sebagainya. Tetapi tidak kalah pentingnya inovasi itu juga dapat berupa produk jasa seperti metode pembelajaran, strategi marketing, cara pelayanan, dan sebagainya.

Dari inovasi diatas ini dapat disimpulkan bahwa secara garis besarnya hanya ada dua jenis inovasi yaitu inovasi produk dan inovasi yang bukan berupa produk (inovasi jasa).

Selengkapnya Djamaludin Ancok (2012:36) menyatakan ada beberapa jenis inovasi yaitu :

1. Inovasi proses

Inovasi proses dapat berupa inovasi dalam proses pembuatan produk, proses layanan, kepada pelanggan dan sebagainya

2. Inovasi metode

Inovasi metode berkaitan dengan metode atau cara melakukan sesuatu seperti metode pembelajaran, metode marketing, dan sebagainya

3. Inovasi struktur organisasi

Inovasi ini merupakan inovasi dalam mengasilkan struktu organisai yang baru.

4. Inovasi dalam hubungan Inovasi ini berusaha menentukan hubungan pelanggan (Cusdomer) dengan produk (Vendor), ehingga dapat memberi banyak keuntungan bagi perusahaan, inovasi dalam hubungan bisnis sangat membantu pengembangan bisnis.

5. Iniovasi strategi

Inovasi strategi merupakan cara yang digunakan organisasi untuk melihat kedunia luar atau keluar organisasi untuk melakukan suatu pembaruan dan mengambil keinginan.

6. Inovasi pada pemikir (mindget) Inivasi pada pemikir merupakan inovasi yang baru guna merubah pola pikir yang lama seperti menganggap karyawan itu malas dan tidak memilki otivasi

7. Inovasi produk

Inovasi produk merupakan inovasi untuk menentukan produk-produk seperti komputer, pesawat terbang, mobil, motor dan sebagainya.

8. Inovasi pelayanan

Inovasi pelayanan merupakan inovasi untuk menetukan bentuk layanan atau service yang baru

\section{B. KAJIAN TEORI}

$>\quad$ Prinsip Inovasi

Prinsif inovasi menurut Peter Drucher dalam Djamaludin Ancok (2012 : 41) adalah sebagai berikut :

1. Inovasi merupakan usaha sistematis dengan tujuan yang jelas

2. Inovasi tidak hanya berdasarkan perseptual ( adanya kebutuhan 
yang nyata ) tetapi juga harus secara konseptual ( adanya konsep atau adanya kebutuhan yang belum nyata )

3. Inovasi harus dimulai dengan adanya ide ide yang sederhana, mudah, fokus pada satu tujuan

4. Inovasi sebaiknya dimulai dengan adanya orang inovasi yang kecil, bila inovasi yang kecil ini sudah berhasil maka barulah dilanjutkan dengan inovasi yang lebih besar.

5. Dalam berinovasi jangan merasa diri kita pintar karena sifat ini akan membuat diri kita kurang hati - hati dalam usaha yang kita lakukan.

\section{$>\quad$ Hambatan Inovasi}

Untuk melakukan inovasi ada hambatan yang dapat kita temui, hambatan untuk melakukan inovasi itu menurut Mochamad Edwar dalam prosiding seminar I internasional dengan tema inovation and creativity in guidance and counseling di UPI Bandung 29 Agustus 2017 dan juga dalam prosiding Seminar Nasional IX Fakultas Ekonomi Universitas Terbuka dan Ikatan Alumni UT (IKA.Ut) di Jakarta, $11 \quad$ November 2017 dinyatakan hambatan inovasi itu adalah sebagai berikut :

1) Pemimpin yang banyak menekan bawahan

2) Pemimpin yang tidak menghargai kreativitas bawahannya

3) Pemimpin yang merasa dirinya pintar sendiri

4) pemimpin yang merasa pendapat orang lain salah semua, kecuali pendapatnya sendiri yang benar

5) pemimpin yang tidak menerima masukan bawahan

6) Pemimpin yang berpikir sulit keluar dari kotak penilainya (Mental Bloc)

7) Pemimpin yang merasa serba tahu sehingga tidak mau menerima masukan dari bawahan.

8) Proses birokrasi yang berbelitbelit

9) Pemimpin yang selalu mengkritik ide-ide bawahan tetapi tidak memberi solusi sebagai sisi positif atau jalan keluarnya

10) Pemimpin yang takut gagal

11) Pemimpin yang takut disaingi oleh bawahannya

12) Pengawasan yang sangat ketat terhadap bawahan

13) Membuat peraturan tanpa diskusi dengan bawahan

14) Harus ada dasar yang jelas untuk permintaan dana, bahan, waktu, himbauan stap dan bawahan

15) Pemimpin yang tidak mau menerima masukan dari bawahan

\section{METODE PENELITIAN}

Metode yang digunakan dalam penelitian ini adalah Tehnik Study Pustaka atau Tehnik Studi Literasi. Dengan tehnik ini peneliti akan menggunakan pendapat atau teori yang dikemukakan para ahli yang terdapat dalam referensi-referensi atau buku-buku maupun jurnal ilmiah yang relevan yang berkaitan dengan pentingnya inovasi dalam organisasi.

\section{HASIL PENELITIAN DAN PEMBAHASAN}

Sumiyanto (Usahawan Indonesia nomor 18 tahun XXV Oktober 2006) menyatakan pentingnya inovasi dalam organisasi disebabkan oleh :

1. Untuk menghadapi persaingan atau kompetisi

Inovasi itu dimulai dari adanya kreativitas menurut Charles W. Prather dan Lina K. Gundry dalam Triguna Priyadharma (2001:14) kreativitas mempengaruhi kaitan dengan aktivitas mengembangkan 
berbagai ide-ide didalam usaha yang dilakukan dan berkembang karena budaya dan struktur yang mendorong timbulnya kreativitas organisasi.

Selanjutnya James AF. Stoner (1986:57) menyatakan tidak mungkin adanya inovasi bila tidak ada kreativitas. Oleh karena kreatifitas itu dapat dibangkitkan, dikembangkan, dan di inplementasikan sebagai suatu inovasi. Kreativitas telah menjadi bagian penting dari kehidupan organisasi, khususnya bila kreativitas itu dapat diwujudkan menjadi motivasi. Tidak hanya sampai kreativitas saja tetapi sebaiknya krativitas itu dapat dijadikan sebagai inovasi.

2. Dapat bertahan hidup dan menjadi yang terdepan.

Dengan inovasi yang dilakukan maka organisasi dapat mempertahankan keberadaannya atau bertahan hidup dan menjadi yang terdepan.

3. Meningkatkan kinerja penjualan Konsumen memang lebih sering tertarik dengan produk-produk baru, apa lagi bila produk itu seiring dengan kebutuhan organisasi.

4. Dapat meningkatkan efesiensi dan kecepatan layanan

Setiap konsumen selalu menginginkan adanya efisiensi dan kemudahan dalam layanan, mereka tidak ingin berbelit-belit dalam layanan yang dapat menyebabkan organisasi mengalami kesulitan. Disatu sisi organisasi harus menemukan inovasi-inovasi, sedangkan disesi yang lain organisasi harus memanfaatkan inovasi-inovasi yang sudah ada agar organisai tidak tertinggal dari yang lain.

5. Inovasi untuk promosi
Adanya inovasi oleh suatu organisasi dapat menjadi promosi bagi suatu organisasi. Oleh karena itu inovasi yang ditemukan suatu organisasi harus di informasikan kepada konsumen agar informasi itu dapat menjadi promosi bagi organisai tersebut.

6. Untuk memenuhi adanya tuntutan pasar

Dengan adanya inovasi akan ditemukan produk baru. Pasar atau konsumen selalu mengharapkan ditemukanya produk baru yang sesuai dengan kebutuhan mereka. Adanaya inovasi akan mewujudkan bahwa organisasi tersebut bersifat inovatif.

7. Dapat menghadapi persaingan Inovasi merupakan penemuan baru. Suatu organisasi dapat melakukan penawaran baru, atau organisasi itu dapat menghadapi penawaran yang sudah ada. Dengan adanya inovasi atau adopsi inovasi maka suatu organisasi mampu menghadapi persaingan.

Konsumen seringkali mengamati prilaku produsen. Konsumen selalu mnginginkan agar organisasi itu tidak hanya berlaku sebagai pengikut (Follower) saja dari inovasi yang ada, tetapi konsumen menunggu kapan adanya inovasi kita dapat menjadi inovatornya atau penemu inovasi yang ada itu bila dapat seperti ini, maka tentu nilai (Volume) suatu organisai dimata konsumen akan meningkat.

8. Inovasi itu untuk kemajuan dan manfaat bersama

Dari adanya inovasi itu akan diperoleh perubahan dan juga pembaruan. Perhatikanlah dengan adanya penemuan telpon 
genggam maka komunikasi dapat menjadi lebih mudah dan lebih cepat bagi masyarakat. Ini artinya inovasi itu membawa kemajuan dan menfaat bersama yang dapat dirasakan masyarakat.

9. Agar organisasi tidak kehilangan muka dari konsumen

Inovasi itu membawa perubahan, perubahan dan kemajuan, walaupun memang tidak selalu demikian. Dengan adanya inovasi itu organisasi beserta seluruh anggota organisasinya tidak merasa kehilangan muka tetapi justru gengsi mereka akan meningkat dihadapan masyarakat atau konsumen.

10. Supaya dapat bertahan hidup

Organisasi perlu menemukan sesuatu yang baru. Ini dimaksudkan agar organisasi itu dapat bertahan hidup. Untuk itu organisasi dapat menentukan sesuatu yang baru atau melakukan inovasi maupun hanya sebagai pengadopsi (Pemakai) saja dari inovasi yang ada itu. Organisasi tidak menentukan seseorang baru, tetapi hanya sebagai pemakai saja.

11. Menampilkan keunggulan organisasi

Jika suatu organisasi mampu menentukan suatu inovasi, maka organisasi itu akan dikatakan sebagi organisasi yang unggul dibandingkan organisasi lain.

12. Menciptakan gairah kerja dan mengurangi kejenuhan karyawan

Adanya inovasi disuatu organisasi dapat menimbulkan gairah atau semangat kerja (Passion, kerja yang baru) sehingga dapat mengurangi kejenuhan dalam bekerja

13. Mendahulukan aktivitas organisasi dalam bekerja
Adanya inovasi seperti penggunaan komputer, telepon genggam, dan sebagainya dapat membantu memudahkan aktivitas anggota dalam organisasi.

14. Dapat menunjukkan kesiapan organisasi

Organisasi yang selau menetukan inovasi atau memanfaatkan inovasi yang ada dapat dinilai oleh konsumen atau masyarakat sebagai organisasi yang sungguh-sungguh dalam menjalankan tugas-tugas atau pekerjaanya.

\section{E. KESIMPULAN DAN SARAN}

1) Kesimpulan

Dari telaah perusahaan yang sudah dilakukan dapat disimpulkan persepsi pentingnya inovasi dalam organisasi adalah sebagai berikut :

a) Untuk menghadapi persaingan atau kompetisi

b) Untuk dapat bertahan hidup menjadi yang terdepan

c) Untuk meningkatkan kerja penjualan

d) Untuk meningkatkan efesiensi dan pencapaian

e) Inovasi untuk promosi

f) Untuk memenuhi adanya tuntutan pasar

g) Untuk menghadapi persaingan

h) Untuk agar organisasi tidak kehilangan muka

i) Inovasi untuk kemajuan dan manfaat bersama

j) Untuk supaya dapat bertahan hidup

k) Untuk menampilkan ketangguhan organisasi

I) Untuk menciptakan gairah kerja dan mengurangi kejenuhan

m) Untuk memudahkan aktivitas dalam bekerja 
2) Saran

Sehubungan kesimpulan tersebut diatas dapat diajukan beberapa saran berikut ini, yaitu :

a) Hidupkan suasana kreatif di organisasi untuk mendorong timbulnya inovasi

b) Dorong bawahan untuk berfikir kreatif

c) Mulai inovasi dari yang kecil untuk menuju inovasi yang lebih besar

d) Sebagai pemimpin jangan selalu menyalahkan bawahan karena ini tidak mendorong bawahan untuk kreatif

e) Gunakan teori ATM agar karyawan terbiasa berinovasi

f) Bantu bawahan untuk berfikir di luar mental blac

g) Biarkan bawahan yang tampil beda karena bawahan yang berani tampil beda itu menunjukan mereka itu kreatif

h) Jangan selalu banyak mendikte bawahan tetapi beri mereka itu kebebasan

i) Hindari kepemimpinan yang otoriter

j) Jangan cepat puas dengan apa yang sudah ada, tetapi perbaiki semua itu, memberi inovasi yang sudah ada

k) Ajak bawahan untuk berpikir divergen dari pada selalu berpikir konvergen sehingga bawahan berpikir kreatif

\section{DAFTAR PUSTAKA}

Ancok, Djamaludin. 2003. Psikologi Kepemimpinan dan Inovasi. Erlangga, Jakarta

AF Stoner. J. 1986. Manajemen. Erlangga, Jakarta

Edwar, Mochammad. 2017. Seminar Internasional Inovation And Creatifvity Dengan judul makalah Creativity and inovation, Universitas Pendidikan Indonesia, Bandung.

Edwar, Mochammad. 2017. Seminar Nasional Fakultas Ekonomi Universitas Terbuka Dengan Judul Makalah Krativitas dan Inovasi dalam Kewirausahaan, Jakarta.

Managemen Usahawan Indonesia, Tahun XXV Oktober 2006

Priyadharma, Triguna. 2001. Kreativitas dan Strategi, Golden Trayon, Jakarta. 